\title{
PENGARUH PELATIHAN DAN LINGKUNGAN ORGANISASI TERHADAP KOMPETENSI SERTA DAMPAKNYA TERHADAP KINERJA PENYULUH PERTANIAN (Studi Pada Dinas Pertanian Dan Peternakan Daerah Provinsi Sulawesi Utara)
}

\author{
Moch. Toha Khuseno
}

\begin{abstract}
This study aims to determine the effect of training on Agricultural Extension competencies; know the effect of the organization's environment on Agricultural Extension competencies; know the effect of training on the performance of Agricultural Extension Workers; know the effect of the organizational environment on the performance of Agricultural Extension Workers; know the training factors and organizational environment on the performance of Agricultural Extension Workers through work competence as an intervening variable. This research was carried out using the exploratory method with a quantitative approach with the research location at the North Sulawesi Provincial Agriculture and Animal Husbandry Department. The number of samples is equal to the total population of 18 people given the small population. Data collection methods used are descriptive statistical analysis and inferential statistical analysis using path analysis with t-test as hypothesis testing. The results showed that training for Agricultural Extension Workers had a significant effect on work competence; the organizational environment also significantly influences the work competency of Agricultural Extension Workers; work Competence has a significant effect on the performance of Agricultural Extension Workers; Training also has a significant effect on the performance of Agricultural Extension Workers; the organizational environment has a positive and significant effect on the performance of agricultural instructors; training and Organizational Environment have a significant effect on the performance of Agricultural Extension Workers through their Work Competencies. There is an increase in the direct influence and indirect effect of each variable. ${ }^{*}$ eprm*
\end{abstract}

Keywords: agriculture instructor, training, organizational environment, work competence, performance

ABSTRAK
Penelitian ini bertujuan untuk mengetahui pengaruh pelatihan terhadap kompetensi Penyuluh Pertanian; mengetahui pengaruh lingkungan organisasi terhadap kompetensi Penyuluh Pertanian; mengetahui pengaruh pelatihan terhadap kinerja Penyuluh Pertanian; mengetahui pengaruh lingkungan organisasi terhadap kinerja Penyuluh Pertanian; mengetahui faktor pelatihan dan lingkungan organisasi terhadap kinerja Penyuluh Pertanian melalui kompetensi kerja sebagai variabel antara (variable intervening). Penelitian ini dilaksanakan dengan menggunakan metode explanatory research dengan pendekatan kuantitatif dengan lokasi penelitian pada Dinas Pertanian dan Peternakan Daerah Provinsi Sulawesi Utara. Jumlah sampel sama dengan jumlah populasi yaitu sebanyak 18 orang mengingat jumlah populasi yang kecil. Metode pengumpulan data yang digunakan yaitu analisa statistik deskriptif dan analisa statisttik inferensial dengan menggunakan path analysis dengan uji-t sebagai pengujian hipotesis. Hasil penelitian menunjukkan bahwa pelatihan bagi Penyuluh Pertanian berpengaruh signifikan terhadap kompetensi kerjanya; Lingkungan organisasi juga berpengaruh signifikan terhadap kompetensi kerja Penyuluh Pertanian; Kompetensi Kerja berpengaruh signifikan terhadap Kinerja Penyuluh Pertanian; Pelatihan juga berpengaruh signifikan terhadap Kinerja Penyuluh Pertanian; Lingkungan Organisasi berpengaruh positif dan signifikan terhadap Kinerja Penyuluh Pertanian; Pelatihan dan Lingkungan Organisasi berpengaruh signifikan terhadap Kinerja Penyuluh Pertanian melalui Kompetensi Kerjanya. Terdapat peningkatan dari pengaruh langsung dan pengaruh tidak langsung dari masing-masing variabel. ${ }^{*}$ prm*

Kata Kunci : penyuluh pertanian, pelatihan, lingkungan organisasi, kompetensi kerja, kinerja 


\section{PENDAHULUAN}

\section{Latar Belakang}

Program Nawa Cita Presiden Joko Widodo di bidang pertanian diantaranya adalah membangun kedaulatan pangan berbasis agrobisnis kerakyatan, pengendalian impor pangan dan pemberantasan mafia impor pangan. Oleh karena itu Kementerian Pertanian telah menetapkan Sebelas Arah Kebijakan Pembangunan Pertanian yang salah satunya adalah pengembangan 8 (delapan) komoditas strategis yaitu padi, jagung, kedelai, tebu, kakao, cabai, bawang merah, dan sapi potong. Tujuan utama dari arah kebijakan pengembangan delapan komoditas tersebut untuk mewujudkan ketahanan pangan yang berkelanjutan dan kemandirian pangan. Pembangunan pertanian tersebut tidak akan berhasil bila semua unsur yang terlibat dalam pembangunan pertanian tidak mampu menunjukan kinerja yang prima dalam pelaksanaan tugas pokok dan fungsinya masing-masing termasuk Penyuluh Pertanian.

Penyuluh pertanian adalah pegawai negeri sipil dan merupakan bagian dari sumberdaya manusia pertanian yang diberi tugas, tanggung jawab, wewenang dan hak secara penuh oleh pejabat yang berwenang pada satuan organisasi lingkup pertanian untuk melakukan kegiatan penyuluhan pertanian. Penyuluhan pertanian merupakan suatu sistem pendidikan di luar sekolah di bidang pertanian untuk petani - nelayan dan keluarganya serta anggota masyarakat, agar dinamika dan kemampuannya dalam memperbaiki kehidupan dan penghidupan mereka dengan kekuatan sendiri dapat berkembang, sehingga dapat meningkatkan peranan dan peran sertanya dalam pembangunan pertanian.

Penyuluhan pertanian diselenggarakan dengan dua misi pokok yaitu pengembangan sumberdaya manusia dan alih teknologi. Pembangunan sumberdaya manusia berintikan pembangunan perilaku dan kemampuan serta pendayagunaan potensi yang dimilki petani dalam upaya peningkatan pendapatan, kesejahteraan, penciptaan lapangan kerja, kesehatan lingkungan serta kelangsungan pembangunan pertanian. Misi alih teknologi dilakukan dengan memberikan pelayanan teknologi dan fasilitasi untuk berkembangnya kemampuan petani-nelayan dalam menemukan dan menerapkan teknologi yang dikembangkan sendiri. Kedua misi tersebut harus dilaksanakan oleh Penyuluh Pertanian.
Menyadari betapa strategisnya peranan Penyuluh Pertanian sebagai pejabat fungsional, dituntut kualifikasi yang memadai, baik dalam aspek intelektual maupun aspek emosional, sehingga performans Penyuluh Pertanian lebih profesional. Penataan pegawai negeri sipil dapat dilakukan dalam konteks peningkatan kinerja dengan membangkitkan segala kemampuan yang ada untuk mencapai tujuan melalui pertumbuhan motivasi inovatif, kreatif, serta pemberian penghargaan dan pengakuan bagi mereka yang berprestasi. Selain itu, untuk mengembangkan dan meningkatkan sumberdaya pegawai, kualitas pegawai dan kelayakan organisasi, sangat dibutuhkan untuk tercapainya pegawai negeri sipil yang penuh kesetiaan dan ketaatan kepada Pancasila dan Undang Undang Dasar 1945.

Seiring dengan diberlakukannya otonomi daerah (UU nomor 22 tahun 1999 yang diubah menjadi UU nomor 32 tahun 2004), maka pengelolaan Penyuluh Pertanian sudah diserahkan kepada masing-masing daerah dimana Penyuluh Pertanian bertugas. Selanjutnya Sumardjo (2008) mengidentifikasi beberapa permasalahan penyuluhan di era otonomi daerah di antaranya; (1) adanya kesalahan persepsi bagi para penyelenggara penyuluhan di daerah, (2) citra penyuluhan dianggap masih kurang baik, (3) apriori di kalangan masyarakat tertentu (NGO) terhadap penyuluhan, (4) dimasa lalu penyuluhan terwarnai oleh muatan politik organisasi politik tertentu, dan (5) di era otonomi penyuluhan ditinggalkan oleh sebagian penguasa di daerah karena tidak jelas dan tidak tampak secara langsung. Untuk mengatasi berbagai permasalahan yang ada, telah lahir Undang-Undang Nomor 16 tahun 2006 tentang Sistem Penyuluhan Pertanian, Perikanan dan Kehutanan. Undang-undang tersebut diharapkan bisa dijadikan payung hukum dalam penyelenggaraan penyuluhan pertanian.

Badan Pengembangan SDM Pertanian (2005) melansir sejak diberlakukan otonomi daerah tersebut, persepsi pemerintah daerah mengenai pentingnya penyuluhan pertanian berbeda-beda. Hal ini mempengaruhi kinerja penyuluhan pertanian di daerah. Banyak Pemerintah Daerah yang tidak memberikan dukungan yang diperlukan bagi Penyuluh Pertanian untuk dapat melakukan bimbingan pendamping kepada kelompok-kelompok tani. Hal ini berdampak pada kompetensi dan Kinerja Penyuluh Pertanian serta dinamika proses belajar berusaha petani di pedesaan. 
Provinsi Sulawesi Utara dengan potensi di bidang pertanian yang menonjol, membutuhkan peran Penyuluh Pertanian dan petugas pertanian lainnya secara optimal. Oleh karena itu sejalan potensi tersebut, apakah kinerja Penyuluh Pertanian di Provinsi Sulawesi Utara dapat berjalan dengan baik, ditengah gencarnya program pembangunan pertanian dalam mengejar target swasembada pangan, sehingga mengharuskan teknologi-teknologi baru yang didukung oleh alat dan mesin pertanian yang modern agar mencapai produktivitas yang tinggi. Sementara kegiatan pelatihan sebagai upaya memberikan pembekalan teknologi-teknologi baru dan pengenalan operasional alat dan mesin pertanian untuk mengantisipasi perkembangan teknologi pertanian dan agribisnis sangat terbatas akibat keterbatasannya anggaran pelatihan.

Dilain pihak organisiasi kelembagaan Penyuluh Pertanian di lingkungan Provinsi Sulawesi Utara juga masih belum mantap. Sejak adanya kelembagaan penyuluhan pertanian, keberadaannya masih berubah-ubah. Pada awalnya Penyuluh Pertanian masuk dalam organisasi Satuan Pembina Harian Bimas Provinsi Sulawesi Utara, kemudian berubah dibawah Kantor Wilayah Departemen Pertanian Propinsi, kemudian Dinas Pertanian. Sejak diterbitkannya Undang Undang Nomor 16 Tahun 2006 maka dibentuklah Badan Koordinasi Penyuluhan Pertanian, Perikanan dan Kehutanan (Bakorluh P2K). Namun sejak diberlakukannya Peraturan Pemerintah Nomor 18 Tahun 2016 tentang Perangkat Daerah, maka keberadaan Bakorluh P2K dihilangkan dan Penyuluh Pertanian kembali berada dibawah Dinas Pertanian dan Peternakan Provinsi Sulawesi Utara. Dengan adanya ketidakpastian organisasi dimungkinkan akan dapat mempengaruhi tingkat kompetensi dan kinerja Penyuluh Pertanian, hal ini karena adanya faktor dari luar organisasi yang dapat melemahkan bahkan bisa menghilangkan organisasi penyuluhan pertanian.

Oleh karena itulah, maka penelitian ini diharapkan mampu memberikan solusi kebijakan program pembangunan penyuluhan pertanian yang tepat agar Penyuluh Pertanian dapat melaksanakan tugas pokok dan fungsinya sebagai pejabat fungsional secara baik dengan kompetensi dan kinerja yang profesional dan dalam lingkungan organisasi yang mantap dengan lokasi penelitian pada Dinas Pertanian dan Peternakan Daerah Provinsi Sulawesi Utara.

\section{Pelatihan}

Berdasarkan Peraturan Menteri Pertanian nomor 37/Permentan/SM.120/8/2018 tanggal 14 Agustus 2018 tentang Pedoman Penyelenggaraan Pelatihan Pertanian, pelatihan adalah setiap usaha atau upaya untuk memperbaiki performan pekerja pada pekerjaan tertentu yang menjadi tanggungjawabnya atau pekerjaan yang berkaitan dengan pekerjaannya. Selanjutnya Bangun (2012) menyatakan bahwa pelatihan merupakan proses untuk mempertahankan atau memperbaiki keterampilan sumber daya manusia untuk menghasilkan pekerjaan yang efektif. Sedangkan Suparyadi (2015) mengatakan bahwa pelatihan merupakan kegiatan untuk meningkatkan keterampilan sumber daya manusia dalam organisasi maupun perusahaan pada bidangbidang keterampilan tertentu. Kasmir (2016) mengungkapkan bahwa pelatihan merupakan proses untuk membentuk dan membekali sumber daya manusia dengan menambah keahlian, kemampuan, pengetahuan dan perilakunya.

Terdapat tiga kondisi yang memungkinkan seseorang memerlukan pelatihan yakni: a) bila seseorang tidak dapat mengerjakan pekerjaan atau tugas sehari-hari, baik seluruhnya maupun sebagian; b) bila seseorang mendapat tambahan tugas baru yang sebagian atau sama sekali asing baginya; dan c) bila seseorang ditempatkan dalam jabatan yang baru memerlukan pengetahuan, sikap dan keterampilan baru. Pendidikan dan latihan (diklat) adalah proses belajar yang dirancang untuk mempengaruhi dan mengubah kompetensi kerja seseorang sehingga dia dapat berprestasi lebih baik dalam jabatannya dan bertambah kompetensinya melalui peningkatan pengetahuan, keterampilan dan sikapnya (Padmowihardjo, 1994).

Mondy dan Wayne (2008) mengungkapkan bahwa pelatihan (training) adalah jantung dari upaya berkelanjutan untuk meningkatkan kompetensi karyawan dan kinerja organisasi. Pelatihan memberi para pembelajar pengetahuan dan ketrampilan yang dibutuhkan untuk pekerjaan mereka saat ini. Disisi lain pelatihan melibatkan pembejaran yang melampau pekerjaan saat ini dan memiliki focus yang lebih jangka panjang.

Dalam program pelatihan harus telah dituangkan sasaran, kebijaksanaan, prosedur, anggaran, peserta, kurikulum dan waktu pelaksanaannya. Program pelatihan ini harus berprinsipkan kepada peningkatan efektivitas dan efisiensi kerja masing-masing karyawan pada jabatannya. Program pelatihan suatu organisasi hendaknya diinformasikan secara terbuka kepada semua karyawan atau anggota supaya mereka mempersiapkan dirinya masing-masing. Menurut Hasibuan (2000) metode pelatihan harus berdasarkan kepada kebutuhan pekerjaan tergantung pada berbagai 543actor yaitu waktu, biaya, jumlah peserta, tingkat pendidikan dasar peserta, latar belakang peserta dan lain-lain. 
Pelatihan adalah proses belajar yang dirancang untuk mengubah kompetensi kerja seseorang. Perubahan kompetensi kerja seseorang hanya akan terjadi apabila ada perubahan perilaku yang mendukung kompetensi kerja tersebut. Aspek perilaku dapat dikelompokkan menjadi tiga unsur yaitu: aspek perilaku kognitif (kemampuan mengingat sesuatu yang telah dipelajari dan mengembangkan intelegensia), aspek perilaku afektif (berhubungan dengan sikap kejiwaan seperti cenderungan, nilai dan `minat), dan aspek perilaku psikomotor (berhubungan dengan ketrampilan gerak fisik).

Selanjutnyat Gomez Mejia dkk (2001) berpendapat bahwa fakus utama dari pelatihan adalah pada pekerjaan yang diemban sekarang. Dan cakupan pelatihan adalah individu para karyawan, sehingga pelatihan terlihat lebih spesifik untuk pekerjaan tertentu dan digunakan untuk mengatasi kekurangan atau masalah kinerja. Nitisemito (2000) indikator dari pelatihan (diklat) adalah sebagai berikut:

1. Keahlian lebih meningkat

2. Pengetahuan pekerjaan akan lebih baik

3. Sikap loyalitas meningkat

4. Kepuasan kerja meningkat

5. Rasa percaya diri meningkat

6. Tingkat kesalahan dapat ditekan

\section{Lingkungan Organisasi}

Lembaga atau institusi kerja pada hakekatnya adalah kelompok atau organisasi masyarakat. Oleh sebab itu instansi ini juga dapat merupakan tempat pemenuhan kebutuhan sosial bagi para karyawannya. Pengorganisasian atau pengelolaan karyawan yang baik dan merupakan manifestasi pengembangan sumberdaya manusia adalah apabila, instansi atau tempat kerja tersebut merupakan suatu tempat yang dapat memenuhi kebutuhan sosial bagi para karyawannya (Notoatmodjo, 2003).

Suatu organisasi tidak hidup sendiri, dimana disekitarnya tumbuh berdampingan dengan banyak lembaga, kelompok, tradisi lain dalam suatu masyarakat, sehingga organisasi merupakan bagian dari suatu sistem yang lebih luas yang mencakup semua ciri masyarakat yang mempengaruhinya. Oleh karena itu suatu organisasi akan berkembang dengan baik bila mampu menangani faktor-faktor eksternal dan internal dengan baik.

Menurut Bryant dan White (1989) organisasi merupakan bagian suatu sistem yang lebih luas yang mencakup semua ciri kemasyarakatan yang mempengaruhinya. Sistem inilah yang merupakan lingkungan suatu organisasi. Analisis keorganisasian makin menekankan pengaruh lingkungan terhadap cara-cara organisasi menjalankan fungsinya dan terhadap jenis-jenis kebijakan yang berkembang.
Peran lingkungan menjadi penting untuk sebuah organisasi dikarenakan:

1. Lingkungan dapat menyediakan sumbersumber daya. Dengan adanya lingkungan yang mampu menyediakan kebutuhan organisasi dalam perkembangannya baik finansial, dukungan politik, teknologi dan lain-lain.

2. Lingkungan menawarkan batas atau kendala, artinya bahwa dengan adanya keterbatasan lingkungan akan menjadi kendala bagi organisasi dalam kehidupan organisasi dan hanya organisasi yang mampu mengelola sebaik mungkin sumberdaya dan kemampuan diri dan keterbatasan lingkungan akan tumbuh menjadi organisasi yang kuat.

Menurut Daniel Katz dan Robert Kahn dalam Bryant dan White (1989) yang mengklasifikasikan kekuatan lingkungan dengan lima sektor lingkungan yaitu nilai-nilai kemasyarakatan, politik, ekonomi, informasi dan teknologi baru, kondisi fisik yang dapat dipengaruhi oleh empat dimensi (matra) yakni kemelut - stabilitas, keseragaman-kebhinekaan, mengelompok-acak dan kelangkaan-keberlebihan.

Dalam organisasi yang tumbuh dalam lima sektor lingkungan yang kurang baik tentunya akan banyak menghadapi kendala dan hambatan dalam perkembangannya, sementara apabila organisasi mampu mengelola empat matra yang mempengaruhi lima sektor lingkungan tadi, maka organisasi akan menjadi tangguh dan mampu berkembang sesuai jaman dan keadaannya.

Oleh karena itu pengaruh lingkungan bisa berdampak positif, apabila organisasi mampu beradaptasi dengan lingkungan dalam pelaksanaan program dan kebijakannya. Sebaliknya akan tenggelam bila tidak mampu mengelola organisasi sesuai tuntutan jaman. Organisasi perlu menemukan cara-cara untuk memelihara dan melindungi dirinya sendiri terhadap upaya-upaya untuk melemahkan pengaruhnya atau untuk mengubah kebijakan. Kendati organisasi bekerja untuk mencapai tujuan, namun banyak tindakannya yang dilakukan sebagai upaya mempertahankan otonomi dan kebebasannya. Suatu cara yang sering digunakan organisasi dalam mencoba melindungi dirinya ialah dengan menunjukkan keberhasilan. Dengan menunjukkan keberhasilan berarti organisasi bisa eksis dan diterima lingkungannya. Upaya lain untuk mencari perlindungan yaitu dengan cara menyendiri dari pengaruh kelompok lain. Hal ini bertujuan untuk mencari jati diri suatu organsasi, sehingga organisasi ini punya spesifikasi yang berbeda dari yang lain, sehingga keberadaannya sangat diperlukan. 


\section{Kompetensi Kerja}

Upaya dalam mencapai keberhasilan pada setiap organisasi baik pemerintah maupun swasta untuk mencapai tujuan organisasinya, diperlukan landasan yang kuat berupa kompetensi. Oleh karena itu, kompetensi menjadi sangat berpenting untuk membantu organisasi meningkatkan kinerjanya. Kompetensi sangat diperlukan dalam setiap proses pengembangan sumber daya manusia. Semakin banyak kompetensi dipertimbangkan, maka semakin meningkat pula kinerjanya. Berdasarkan Surat Keputusan Menteri Pertanian Nomor 37/PERMENTAN/SM.120/ 8/2018 tanggal 7 Agustus 2018 tentang Pedoman Pelatihan Pertanian, kompetensi adalah kemampuan dan karakteristik yang dimiliki seorang Aparatur dan atau Non Aparatur Pertanian berupa pengetahuan, ketrampilan dan sikap perilaku yang diperlukan dalam pelaksanaan tugas jabatan dan pekerjaannya. Selanjutnya Spencer (1993), kompetensi adalah karakteristik yang mendasari seseorang berkaitan dengan efektivitas kinerja individu dalam pekerjaannya atau karakteristik dasar individu yang memiliki hubungan kausal atau sebagai sebab-akibat dengan kriteria yang dijadikan acuan. Katz Reesenzweig dalam Gibson (1999) mengatakan bahwa kemampuan seseorang pegawai pelaksana yang cocok dimiliki oleh setiap organisasi modern (administrator) adalah: 1. Keterampilan teknis; 2. Keterampilan kemanusiaan; 3. Keterampilan konseptual. Kompetensi merupakan suatu kemampuan untuk melaksanakan atau melakukan suatu pekerjaan atau tugas yang dilandasi atas keterampilan dan pengetahuan serta didukung oleh sikap kerja yang dituntut oleh pekerjaan tersebut. Dengan demikian, kompetensi menunjukkan keterampilan dan pengetahuan yang dicirikan oleh profesionalisme dalam suatu bidang tertentu sebagai sesuatu yang terpenting atau sebagai unggulan bidang tersebut. Karena pada umumnya kompetensi menyangkut kemampuan dasar seseorang untuk melakukan pekerjaan (Moeheriono, 2009).

Peningkatan kemampuan kerja dilakukan dengan upaya peningkatan aspek-aspek yang mendasari unsur tersebut yakni pengetahuan dan keterampilan kerja individu serta peningkatan motivasi serta situasi/lingkungan yang mendorong timbulnya kepuasan dan kemauan kerja individu. Kebutuhan tenaga-tenaga terampil didalam berbagai bidang sudah merupakan tuntutan dunia global yang tidak dapat ditunda dan dituntut untuk memiliki kemampuan dalam membuat rencana pengembangan SDM yang berkualitas, dengan melakukan perbaikan kedalam, yang salah satunya melalui pengembangan SDM. Kualitas sumber daya manusia merupakan salah satu faktor untuk meningkatkan produktivitas kinerja suatu organisasi atau instansi. Oleh karena itu, diperlukan sumber daya manusia yang mempunyai kompetensi tinggi karena kompetensi akan dapat mendukung peningkatan prestasi kinerja pegawai.

Menurut Tjitropranoto (2003), bahwa penyuluh pertanian tidak mampu bahkan tidak sempat mengembangkan kemampuan profesionalnya sebagai pejabat fungsional penyuluh, karena banyaknya kegiatan yang ditetapkan atasannya, yang kadang-kadang tidak sesuai dengan tugas sebagai Penyuluh Pertanian professional. Sumardjo (2008) menjelaskan bahwa rendahnya kompetensi penyuluh antara lain diduga berkaitan dengan proses pembelajaran yang kurang bermutu, karena penyuluh terjebak pada tuntutan formalitas untuk penyesuaian ijasah bagi jabatan fungsional penyuluh. Kompetensi para penyuluh itu bersifat dinamis. Kompetensi perlu disesuaikan sejalan dengan perubahan dan perkembangan ilmu pengetahuan, teknologi dan perubahan profil khalayak penyuluhan.

Menurut Boyatzis (1984) kompetensi adalah kemampuan dan keterampilan yang dimiliki seseorang untuk melakukan pekerjaan/tugas guna mencapai tujuan. Kompetensi, menurut Spencer dan Spencer (1993), adalah segala bentuk motif, sikap, keterampilan, perilaku atau karakteristik pribadi lain yang penting untuk melaksanakan pekerjaan atau membedakan antara kinerja rata-rata dengan kinerja superior. Lebih jauh Spencer dan Spencer (1993) menegaskan bahwa dalam individu terdapat lima tipe kompetensi yaitu motif (motives), sifat bawaan (traits), konsep diri (self concept), pengetahuan (knowledge), dan keterampilan (skills).

Wujud perilaku dalam melaksanakan tugas pekerjaan dapat disebut sebagai kemampuan. Konsep kompetensi mengacu pada pemikiran, dan dapat disarikan bahwa kompetensi adalah kemampuan yang dilandasi oleh pengetahuan, keterampilan, dan didukung oleh sikap yang dituntut dalam melaksanakan tugas pekerjaan. Ini berarti kompetensi Penyuluh Pertanian adalah kemampuan yang dilandasi oleh pengetahuan, keterampilan, dan didukung oleh sikap yang dituntut dalam melaksanakan tugasnya dalam memberdayakan petani. Hakekat penyuluhan adalah pendidikan non formal dalam mengubah perilaku sasaran baik dalam aspek kognitif, afektif, maupun psikomotor ke arah yang lebih baik sesuai dengan potensi dan kebutuhan. Dalam penyuluhan, klien atau sasaran merupakan subjek, bukan sebaliknya menjadi objek. Menurut Sumardjo (1999), filosofi dan prinsip-prinsip penyuluhan dalam arti yang sebenarnya adalah partisipatif, dialogis, konvergen, dan demokratis, sehingga memberdayakan, dan bukannya praktek-praktek penyuluhan yang bersifat top down, linier dan bertentangan dengan filosofi pembangunan manusia. 
Rogers (1983) mengemukakan bahwa seorang penyuluh dikatakan kompeten apabila dia berhasil melaksanakan serangkaian tugasnya yang mencakup; (1) kemauan dan kemampuan penyuluh untuk menjalin hubungan secara langsung maupun tidak langsung dengan masyarakat sasarannya; (2) kemauan dan kemampuan penyuluh untuk menjadi perantara/mediator antara sumber-sumber inovasi dengan pemerintah, lembaga penyuluhan dan masyarakat sasarannya; dan (3) kemauan dan kemampuan penyuluh untuk menyesuaikan kegiatankegiatan yang dilakukan dengan kebutuhan yang dapat dirasakan oleh pemerintah atau lembaga penyuluhan dan masyarakat sasarannya.

Berdasarkan tugas-tugas penyuluh, tuntutan kompetensi sesuai dengan kebutuhan masyarakat, hasil-hasil penelitian terdahulu dan teori-teori terkait dengan kompetensi yang telah dijelaskan terdahulu, maka dapat dirumuskan kompetensi Penyuluh Pertanian dalam pembangunan pertanian yaitu (1) keefektivan komunikasi, (2) pemanfaatan media internet, (3) membangun jejaring kerja, (4) mengakses informasi, (5) pemahaman inovasi, (6) bekerjasama dalam tim, (7) analisis masalah, (8) berpikir secara sistem/logis, (9) pemahaman potensi wilayah, dan (10) pemahaman kebutuhan petani.

\section{Kinerja Penyuluh Pertanian}

Hasibuan (2000) mengemukakan bahwa kinerja (prestasi kerja) adalah suatu hasil kerja yang dicapai seseorang dalam melaksanakan tugas-tugas yang dibebankan kepadanya yang didasarkan atas kecakapan, pengalaman, dan kesungguhan serta waktu. Selanjutnya Thoha (2004) mengatakan bahwa kinerja adalah gambaran mengenai tingkat pencapaian pelaksanaan suatu kegiatan/program/ kebijakan dalam mewujudkan sasaran, tujuan, misi dan visi organisasi yang tertuang dalam strategic planning organisasi.

Kinerja adalah hasil atau tingkat keberhasilan seseorang secara keseluruhan selama periode tertentu dalam melaksanakan tugas dibandingkan dengan berbagai kemungkinan, seperti standard hasil kerja, target atau sasaran maupun kriteria yang ditentukan terlebih dahulu dan telah disepakati bersama. Istilah kinerja atau penampilan kerja seringkali disamakan dengan istilah yang lain yaitu job performance. Teori tentang job performance adalah teori psikologi tentang proses tingkah laku kerja seseorang sehingga ia menghasilkan sesuatu yang menjadi tujuan dari pekerjaannya. Menurut Prawirosentono (1992) kinerja merupakan suatu hasil kerja yang dicapai oleh seseorang atau kelompok orang dalam organisasi, sesuai dengan wewenang dan tanggung jawab masing-masing, dalam rangka mencapai tujuan organisasi bersangkutan secara legal, tidak melanggar hukum dan sesuai dengan moral dan etika. Kinerja dalam menjalankan fungsinya tidak berdiri sendiri, tetapi berhubungan dengan kemampuan dan motivasi kerja. Oleh karena itu menurut Keith Davis (dalam Mangkunegara, 2005), ada dua faktor utama yang mempengaruhi kinerja individu yakni kemampuan (ability), dan motivasi kerja (motivation) individu tersebut. Kemampuan individual tergantung dari tingkat pengetahuan (knowledge) yang dimiliki, latar belakang pendidikan, dan ketrampilan (skill) yang dikuasai. Sedangkan motivasi kerja individual tergantung sikap (attitude) sebagai motivasi dasar dan lingkungan yang mempengaruhi motivasi tersebut.

Dari definisi di atas dapat disimpulkan bahwa kinerja mempunyai beberapa elemen yaitu:

1) Hasil kerja dicapai secara individual atau secara institusi, yang berarti

2) kinerja tersebut adalah hasil akhir yang diperoleh secara sendiri-sendiri atau kelompok.

3) Dalam melaksanakan tugas, orang atau lembaga diberikan wewenang dan tanggung jawab, yang berarti orang atau lembaga diberikan hak dan kekuasaan untuk ditindak lanjuti, sehingga pekerjaannya dapat dilakukan dengan baik.

4) Pekerjaan haruslah dilakukan secara legal yang berarti dalam melaksanakan tugas individu atau lembaga tentu saja harus mengikuti aturan yang telah ditetapkan.

5) Pekerjaan tidaklah bertentangan dengan moral atau etika artinya selain mengikuti aturan yang ada yang telah ditetapkan, tentu saja pekerjaan tersebut haruslah sesuai moral dan etika yang berlaku umum.

\section{Penyuluh dan Penyuluhan Pertanian}

Penyuluh Pertanian adalah Pegawai Negeri Sipil (PNS) yang diberi tugas, tanggung jawab, wewenang dan hak secara penuh oleh pejabat yang berwenang pada satuan organisasi lingkup pertanian untuk melakukan kegiatan penyuluhan pertanian. Penyuluhan Pertanian merupakan suatu sistem pendidikan di luar sekolah di bidang pertanian untuk petani - nelayan dan keluarganya serta anggota masyarakat, agar dinamika dan kemampuannya dalam memperbaiki kehidupan dan penghidupan mereka dengan kekuatan sendiri dapat berkembang, sehingga dapat meningkatkan peranan dan peran sertanya dalam pembangunan pertanian.

Mosher (1991) menyatakan peranan Penyuluh Pertanian ialah untuk membantu petani supaya mereka dapat menarik yang sebesar-besarnya dari kesempatankesempatan yang ada untuk meningkatkan daya produksi mereka sesuai dengan kemungkinankemungkinan yang ada pada masing-masing lokalitas. Oleh karena itu tugas pokok penyuluh pertanian adalah melakukan kegiatan penyuluhan pertanian untuk 
mengembangkan kemampuan petani - nelayan dalam menguasai, memanfaatkan dan menerapkan teknologi baru, sehingga mampu bertani, berusaha tani lebih menguntungkan serta membina kehidupan berkeluarga yang lebih sejahtera (Anonimous, 1995).

Dalam Undang-undang No 16 tahun 2006 disebutkan bahwa penyuluhan pertanian didefinisikan sebagai proses pembelajaran bagi petani dan keluarganya serta pelaku usaha pertanian lainnya agar mereka mau dan mampu menolong dan mengorganisasikan dirinya dalam mengakses informasi pasar, teknologi, permodalan dan sumberdaya lainnya, sebagai upaya untuk meningkatkan produktivitas, efisiensi usaha, pendapatan dan kesejahteraannya. Untuk mencapai tujuan penyuluhan, seorang penyuluh dalam kaitannya dengan pelaksanaan tugasnya perlu memahami falsafah dan prinsip-prinsip penyuluhan.

Fungsi penyuluhan pertanian adalah : (a) menyebarkan informasi pertanian, (b) mengajar pengetahuan dan ketrampilan pertanian yang lebih baik dan menguntungkan, (c) memberikan rekomendasi usahatani yang lebih menguntungkan, (d) mengusahakan fasilitas usahatani yang lebih menggairahkan melalui jalinan hubungan yang lebih baik antara petani dengan pihak-pihak pelaksana pelayanan, dan (e) menumbuhkan swadaya petani dan kelompok tani (Samsudin, 1977). Selanjutnya Soedarmanto (1989) tujuan penyuluhan pertanian adalah untuk menambah pengetahuan, ketrampilan dan mengubah sikap petani dalam mengusahakan usahataninya ke arah bertani lebih baik (better farming), berusahatani lebih menguntungkan (better bussines) dan hidup lebih sejahtera (better living).

Dalam penyelenggaraan penyuluhan dewasa ini dan yang akan datang, pemerintah akan lebih berfungsi sebagai regulator, fasilitator dan katalisator pembangunan. Dengan demikian penyuluhan pertanian dapat menjadi gerakan masyarakat di daerah-daerah guna meningkatkan produktivitas, daya saing dan pendapatan masyarakat yang pada gilirannya dapat memberikan kontribusi nyata pada pendapatan asli daerah (Saragih, 2002).

Penyelenggaraan penyuluhan pertanian di masa depan harus dapat mendorong peran serta aktif petani, pelaku usaha pertanian dan stakeholder lainnya. Hal ini sesuai dengan paradigma baru pembangunan pertanian yang menekankan berkembangnya prakarsa dan kreativitas masyarakat sesuai dengan semangat UU No. 22 tahun 1999 yang telah diganti dengan UU No. 32 tahun 2004 tentang Pemerintahan Daerah.
Saragih (2002) menyarankan agar dalam penyelenggaraan penyuluhan pertanian para penyelenggara penyuluhan pertanian harus melihat petani sebagi manajer usahataninya yang merupakan subsistem dari sistem dan usaha agribisnis. Petani adalah sosok yang memiliki potensi dan kemampuan untuk mengambil keputusan sendiri dalam merencanakan, mengelola dan mengembangkan usahataninya untuk kesejahteraan dirinya, keluarganya, masyarakat dan lingkungan sekitarnya.

Selanjutnya Martins dkk (1997) menyatakan bahwa tujuan penyuluhan pertanian dalam pembangunan sistem dan usaha agribisnis adalah meningkatkan pendapatan dan kesejahteraan petani dan keluarganya beserta masyarakat pelaku agribisnis melalui peningkatan produktivitas dan efisiensi usaha dengan cara meningkatkan kemampuan dan keberadaan mereka. Untuk mencapai tujuan tersebut maka kegiatan penyuluhan meliputi : (1) menfasilitasi proses pembelajaran petani dan keluarganya beserta masyarakat pelaku agribisnis, (2) memberikan rekomendasi dan mengikhtiarkan akses petani dan keluarganya ke sumber-sumber informasi dan sumber daya yang akan membantu mereka dalam memecahkan masalah yang dihadapi, (3) membantu menciptakan iklim usaha yang menguntungkan, (4) mengembangkan organisasi petani menjadi organisasi sosial ekonomi yang tangguh dan (5) menjadikan kelembagaan penyuluhan sebagai lembaga mediasi dan intermediasi, terutama yang menyangkut teknologi dan kepentingan petani dan keluarganya beserta masyarakat pelaku agribisnis (Hubies dan Vitayala, 1996).

Keberhasilan penyuluhan pertanian akan berkorelasi langsung dengan keberhasilan pembangunan pertanian. Penyuluhan pertanian memiliki kaitan yang kuat dengan pembangunan pertanian. Perubahan yang terjadi terkait dengan pembangunan pertanian akan memiliki konsekwensi langsung terhadap penyuluhan pertanian.

\section{Hipotesis}

Dari kerangka pikir diatas, maka hipotesis dalam penelitian ini adalah:

1. Terdapat pengaruh signifikan antara pelatihan terhadap kompetensi Penyuluh Pertanian di Provinsi Sulawesi Utara.

2. Terdapat pengaruh signifikan antara lingkungan organisasi terhadap peningkatan Kompetensi Penyuluh Pertanian di Provinsi Sulawesi Utara.

3. Terdapat pengaruh signifikan antara kompetensi terhadap Kinerja Penyuluh Pertanian di Provinsi Sulawesi Utara.

4. Terdapat pengaruh signifikan antara pelatihan terhadap Kinerja Penyuluh Pertanian di Provinsi Sulawesi Utara. 
5. Terdapat pengaruh signifikan antara lingkungan organisasi terhadap peningkatan Kinerja Penyuluh Pertanian di Provinsi Sulawesi Utara.

6. Adanya hubungan antara pelatihan dan lingkungan organisasi yang baik akan meningkatkan kinerja melalui kompetensi kerja Penyuluh Pertanian di Provinsi Sulawesi Utara.

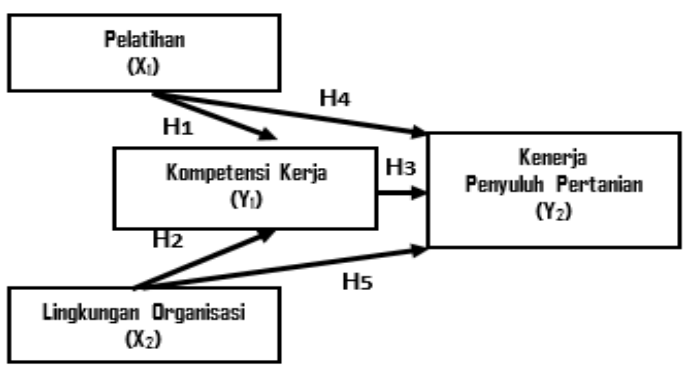

Gambar 1. Model Hipotesis

\section{Rumusan Masalah}

1. Bagaimana pengaruh pelatihan terhadap kompetensi Penyuluh Pertanian di Provinsi Sulawesi Utara.

2. Bagaimana pengaruh lingkungan organisasi terhadap kompetensi Penyuluh Pertanian di Provinsi Sulawesi Utara.

3. Bagaimana pengaruh pelatihan terhadap kinerja Penyuluh Pertanian di Provinsi Sulawesi Utara.

4. Bagaimana pengaruh lingkungan organisasi terhadap kinerja Penyuluh Pertanian di Proivinsi Sulawesi Utara.

5. Sejauh mana faktor pelatihan dan lingkungan organisasi terhadap kinerja Penyuluh Pertanian melaui kompetensi kerja sebagai variable intervening di Provinsi Sulawesi Utara.

\section{Tujuan Penelitian}

1. Untuk mengetahui pengaruh pelatihan terhadap kompetensi Penyuluh Pertanian di Provinsi Sulawesi Utara.

2. Untuk mengetahui pengaruh lingkungan organisasi terhadap kompetensi Penyuluh Pertanian di Provinsi Sulawesi Utara.

3. Untuk mengetahui pengaruh pelatihan terhadap kinerja Penyuluh Pertanian di Provinsi Sulawesi Utara.

4. Untuk mengetahui pengaruh lingkungan organisasi terhadap kinerja Penyuluh Pertanian di Provinsi Sulawesi Utara.

5. Untuk mengetahui faktor pelatihan dan lingkungan organisasi terhadap kinerja Penyuluh Pertanian melalui kompetensi kerja sebagai variable intervening di Provinsi Sulawesi Utara.

\section{Manfaat Penelitian}

1. Sebagai sumbang pikiran kepada Pemerintah Provinsi Sulawesi Utara dan Pemerintah Pusat tentang pola peningkatan kinerja Penyuluh Pertanian yang tepat.

2. Sebagai bahan retropeksi diri bagi rekan-rekan Penyuluh Pertanian dalam mengatur kinerja dirinya untuk peningkatan produktivitas kerjanya.

3. Dapat bermanfaat untuk pengembangan dan pengetahuan yang berhubungan dengan pengembangan sumberdaya manusia pertanian khususnya sumberdaya manusia penyuluhan pertanian.

\section{METODE PENELITIAN}

Penelitian ini merupakan penelitian penjelasan (explanatory research) dengan pendekatan kuantitatif (Sugiono, 2008). Penelitian dilakukan kepada para Penyuluh Pertanian di Dinas Pertanian dan Peternakan Daerah Provinsi Sulawesi Utara. Jumlah responden sebanyak jumlah populasinya yaitu 18 orang. Teknik pengambilan sampel yang digunakan adalah sensus karena populasinya yang kecil dan metode pengumpulan data.

\section{HASIL DAN PEMBAHASAN}

Gambaran Pelatihan $\left(\mathbf{X}_{1}\right)$, Lingkungan Organisasi $\left(\mathbf{X}_{2}\right)$, Kompetensi $\left(\mathbf{Y}_{1}\right)$, dan Kinerja Karyawan $\left(\mathbf{Y}_{2}\right)$.

Berdasarkan hasil penelitian yang dilakukan pada pertengahan Tahun 2019 dan mendapatkan data primer melalui kuisioner yang telah diberikan kepada 18 orang Penyuluh Pertanian yang berkerja di Dinas Pertanian dan Peternakan Daerah Provinsi Sulawesi Utara, maka diperoleh mean untuk variabel Pelatihan $\left(\mathrm{X}_{1}\right)$ dengan skor 4,35. Sedangkan mean untuk Variabel Lingkungan Organisasi $\left(\mathrm{X}_{2}\right)$ sebesar 4,34 dan keduanya dapat dikategorikan baik.

Hasil mean Kompetensi Kerja ( $\left.\mathrm{Y}_{1}\right)$ pada Dinas Pertanian dan Peternakan Daerah Provinsi Sulawesi Utara sebesar 4,60 dan hasil mean Kinerja Penyuluh Pertanian $\left(\mathrm{Y}_{2}\right)$ pada Dinas Pertanian dan Peternakan Daerah Provinsi Sulawesi Utara sebesar 4,68 oleh karena itu keduanya dapat dikategorikan baik hingga sangat baik. Berdasarkan deskripsi diatas, dapat disimpulkan bahwa variabel Pelatihan, Lingkungan Organisasi, Kompetensi Kerja, dan Kinerja Penyuluh Pertanian pada Dinas Pertanian dan Peternakan Daerah Provinsi Sulawesi Utara dikategorikan baik. 
Tabel 1. Koefisien Hubungan Pelatihan $\left(X_{1}\right)$ dan Lingkungan Organisasi ( $\left.\mathbf{X}_{2}\right)$ Terhadap Kompetensi Kerja Penyuluh Pertanian $\left(\mathrm{Y}_{1}\right)$

\begin{tabular}{cccccc}
\hline $\begin{array}{c}\text { Variabel } \\
\text { Terikat }\end{array}$ & $\begin{array}{c}\text { Variabel } \\
\text { Bebas }\end{array}$ & $\begin{array}{c}\text { Std Koef } \\
\boldsymbol{\beta}\end{array}$ & T Hitung & Prob & Ket \\
\hline \multirow{2}{*}{$\mathrm{Y}_{1}$} & $\mathrm{X}_{1}$ & 0.511 & 3.357 & 0.004 & $\mathrm{Sig}$ \\
& $\mathrm{X}_{2}$ & 0.473 & 3.109 & 0.007 & Sig \\
\hline \multicolumn{5}{r}{$\mathrm{R}_{1}{ }_{1}: 0,794$} \\
\end{tabular}

Sumber: Data diolah, 2019

\section{Pengaruh Pelatihan $\left(\mathbf{X}_{1}\right)$ terhadap Kompetensi} Kerja Penyuluh Pertanian $\left(\mathbf{Y}_{1}\right)$

Hasil dari analisa data dapat disimpulkan bahwa Pelatihan $\left(\mathrm{X}_{1}\right)$ memiliki pengaruh yang signifikan terhadap Kompetensi Kerja $\left(\mathrm{Y}_{1}\right)$. Hasil tersebut didapatkan dari penelitian yang telah dilakukan yang menunjukan bahwa nilai koefisien Beta sebesar 0,511, dengan nilai t sebesar 3,357 dan nilai probalitas sebesar 0,004 (Tabel 1), dimana tingkat signifikasi jauh lebih kecil dibandingkan nilai alpha sebesar $0,05(0,813<\alpha=$ $0,05)$.

Memang pada saat ini Penyuluh Pertanian diperhadapkan oleh permasalahan akan kompetensi kerja yang rendah, sementara tuntutan tugas pokok dan fungsi Penyuluh Pertanian dalam mensukseskan pembangunan pertanian sangat menantang yaitu terwujudnya kemndirian pangan. Oleh karena itu kompetensi Penyuluh Pertanian harus sebanding dengan tuntutan pekerjaannya tersebut. Hal inilah dibutuhkan pelatihan, walaupun dengan keterbatasan kesempatan pelatihan bagi Penyuluh Pertanian akibat dari keterbatasan anggaran pengembangan sumber daya manusia penyuluh. Maka diperlukan terobosan agar pelatihan tetap dilaksanakan oleh instansi pembinanya dalam kondisi keterbatasan anggaran yang ada.

Bangun (2012) menyatakan bahwa pelatihan merupakan proses untuk mempertahankan atau memperbaiki ketrampilan sumber daya manusia untuk menghasilkan pekerjaan yang efektif. Seiring dengan program pembangunan yang dicanangkan oleh Kementerian Pertanian, maka Penyuluh Pertanian sebagai mitra petani dituntut untuk selalu menguasai ilmu dan teknologi pertanian yang terus berkembang dengan pesat dalam upaya mencapai kemandirian pangan. Hal ini dapat terjadi apabila Penyuluh Pertanian selalu diberi kesempatan seluas-luasnya dalam mengembangkan kompetensi kerjanya.

\section{Pengaruh Lingkungan Organisasi $\left(\mathbf{X}_{2}\right)$ terhadap Kompetensi Kerja $\left(\mathbf{Y}_{1}\right)$ Penyuluh Pertanian}

Lingkungan Organisasi $\left(\mathrm{X}_{2}\right)$ juga mempunyai pengaruh yang signifikan terhadap kompetensi kerja $\left(\mathrm{Y}_{1}\right)$. Hal tersebut didapatkan dari hasil penelitian yang menunjukan nilai koefisien beta sebesar 0,473 dengan nilai $\mathrm{t}$ hitung sebesar 3,109 dimana tingkat probabilitasnya sebesar 0,007 (Tabel 1) yang menunjukkan tingkat signifikasi yang lebih kecil dibanding nilai alpha $0,05(0,800<\alpha=0,05)$.
Lingkungan organisasi harus dibangun agar organisasi mampu menemukan cara memelihara dan melindungi dirinya terhadap upaya untuk melemahkan pengarruhnya atau untuk mengubah kebijakannya. Pengorganisasian atau pengelolaan karyawan yang baik dan merupakan manifestasi pengembangan sumberdaya manusia adalah apabila, instansi atau tempat kerja tersebut merupakan suatu tempat yang dapat memenuhi kebutuhan sosial bagi para karyawannya (Notoatmodjo, 2003).

Suatu organisasi tidak hidup sendiri, dimana disekitarnya tumbuh berdampingan dengan banyak lembaga, kelompok, tradisi lain dalam suatu masyarakat, sehingga organisasi merupakan bagian dari suatu sistem yang lebih luas yang mencakup semua ciri masyarakat yang mempengaruhinya. Oleh karena itu suatu organisasi akan berkembang dengan baik bila mampu menangani faktor-faktor eksternal dan internal dengan baik. Lingkungan organisasi yang kondusif akan mampu memberikan tempat dan ruang gerak Penyuluh Pertanian dalam pengembangan kompetensi kerjanya. Oleh karena itu lingkungan organisasi yang baik harus mampu memberikan kesempatan seluasluasnya kepada Penyuluh Pertanian untuk mengembangkan kompetensinya guna memenuhi tuntutan pekerjaan yang menjadi tanggung jawabnya. Kelembagaan Penyuluhan Pertanian harus eksis dan tidak berubah-ubah, agar penyelenggaraan penyuluhan pertanian bisa berjalan dengan baik dan lancer dan Penyuluh Pertanian sebagai motor penggerak penyuluhan pertanian bisa melaksanakan dengan sebaik-baiknya.

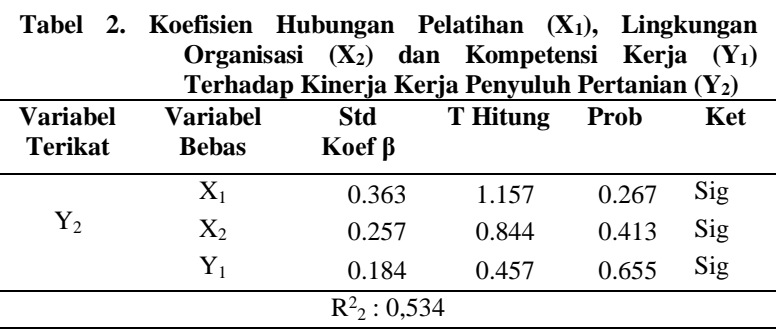

Sumber: Data diolah, 2019

\section{Pengaruh Kompetensi Kerja ( $\left.\mathbf{Y}_{1}\right)$ terhadap Kinerja Penyuluh Pertanian $\left(\mathbf{Y}_{2}\right)$}

Dari hasil olah data diperoleh simpulan bahwa

Kompetensi Kerja $\left(\mathrm{Y}_{1}\right)$ memiliki pengaruh yang signifikan terhadap terhadap Kinerja Penyuluh Pertanian $\left(\mathrm{Y}_{2}\right)$. Hasil tersebut didapatkan dari nilai koefisien Beta sebesar 0,184 dengan nilai $\mathrm{t}$ sebesar 0,457 dan tingkat signifikasi sebesar 0,655 sebagaimana tercantum dalam Tabel 2 ternyata lebih kecil dibanding dengan nilai alpha $0,05(0,684<\alpha=0,05)$.

Kompetensi kerja yang dimiliki Penyuluh Pertanian digunakan untuk memaksimalkan kinerja yang dibutuhkan untuk menyelesaikan pekerjaan sebagai Penyuluh Pertanian. Semakin lengkap dan 
tinggi kompetensi yang dimiliki Penyuluh Pertanian akan diikuti dengan peningkatan kinerja yang signifikan. Hal ini didukung oleh pendapat Rogers (1983) mengemukakan bahwa seorang penyuluh dikatakan kompeten apabila dia berhasil melaksanakan serangkaian tugasnya yang mencakup; (1) kemauan dan kemampuan penyuluh untuk menjalin hubungan secara langsung maupun tidak langsung dengan masyarakat sasarannya; (2) kemauan dan kemampuan penyuluh untuk menjadi perantara/mediator antara sumbersumber inovasi dengan pemerintah, lembaga penyuluhan dan masyarakat sasarannya; dan (3) kemauan dan kemampuan penyuluh untuk menyesuaikan kegiatan-kegiatan yang dilakukan dengan kebutuhan yang dapat dirasakan oleh pemerintah atau lembaga penyuluhan dan masyarakat sasarannya.

Hal tersebut menjelaskan bahwa untuk melakukan pekerjaan dibutuhkan kompetensi kerja yang baik sehingga kinerja yang dihasilkan maksimal.

\section{Pengaruh Pelatihan $\left(\mathbf{X}_{1}\right)$ terhadap Kinerja Penyuluh Pertanian $\left(\mathbf{Y}_{2}\right)$}

Pengaruh Pelatihan $\left(\mathrm{X}_{1}\right)$ memiliki signifikansi yang nyata terhadap Kinerja Penyuluh Pertanian $\left(\mathrm{Y}_{2}\right)$. Hal tersebut didukung oleh hasil penelitian yang telah dilakukan yang menunjukan bahwa nilai Koefisien $\beta$ eta sebesar 0,363 dengan nilai t sebesar 1,157 dan nilai probabilitasnya sebesar 0,267 sebagaimana tercantum dalam Tabel 2 dan nilai tersebut signifikasinya lebih kecil dibanding dengan nilai alpha 0,05 $(0,676<\alpha=$ $0,05)$.

Pelaksanaan pelatihan harus didesain sedemikian rupa sehingga sesuai kebutuhan organisasi dan karyawannya agar hasilnya berdampak positif pada kinerja Penyuluh Pertanian, maka dari itu faktor-faktor yang terlibat dalam penyelenggaraan pelatihan harus benar-benar dipersiapkan dengan matang agar mencapai hasil kinerja yang diinginkan. Hal tersebut didukung oleh Suparyadi (2015) menyatakan bahwa pelatihan sebagai suatu proses pembelajaran harus dilakukan secara sistematis agar dapat mencapai hasil yang optimal. Bila penyelenggaraan pelatihan dilaksanakan sesuai dengan kebutuhan organisasi dan karyawannya, maka hasilnya akan tampak nyata pada peningkatan kinerja yang dihasilkannya.

\section{Pengaruh Lingkungan Organisasi $\left(\mathrm{X}_{2}\right)$ terhadap Kinerja Penyuluh Pertanian ( $\left.\mathrm{Y}_{2}\right)$}

Lingkungan organisasi $\left(\mathrm{X}_{2}\right)$ juga mempunyai pengaruh yang signifikan terhadap Kinerja Penyuluh Pertanian $\left(\mathrm{Y}_{2}\right)$. Hasil tersebut diperoleh dari penelitian yang telah dilakukan yang ditunjukan oleh nilai koefisien beta sebesar 0,257 dengan nilai t sebesar 0,844 dan nilai probabilitasnya mencapai 0,413 sebagaimana tercantum dalam Tabel 2, tingkat signifikansinya lebih kecil dibanding nilai alpha $0,05(0,635<\alpha=0,05)$.
Menurut Sukriah (2009) organisasi berada dalam suatu lingkungan yang dapat menjadi faktor pendukung maupun penghambat organisasi. Kegiatan organisasi akan merubah lingkungan dan juga sebaliknya, lingkungan akan mendorong perubahan pada organisasi. Suatu cara yang sering digunakan organisasi dalam mencoba melindungi dirinya ialah dengan menunjukkan keberhasilan. Dengan menunjukkan keberhasilan berarti organisasi bisa eksis dan diterima lingkungannya. Oleh karena itu organisasi penyuluhan pertanian yang selama ini sering mengalami perubahan struktur dan kelembagaan, diharapkan agar kedepan bisa eksis dan kondusif serta bisa menunjukkan prestasi kerjanya yang diakui oleh lingkungan organisasinya. Karena bila lingkungan organisasi yang tidak kondusif akan berakibat pada penyelenggaraan penyuluhan pertanian yang tidak optimal.

Selanjutnya untuk menjelaskan hubungan struktural dari keempat variabel yang diteliti maka perlu dicari $\mathrm{R}^{2}$ model yaitu :

$$
\begin{aligned}
\mathrm{R}^{2} \text { model } & =1-\left(1-\mathrm{R}^{2}\right)\left(1-\mathrm{R}^{2}{ }_{2}\right) \\
& =1-(1-0,794)(1-0,534) \\
& =1-(0,206)(0,466) \\
& =1-0,095996 \\
& =0,9040 \text { atau } 90,40 \%
\end{aligned}
$$

Dari hasil perhitungan ketetapan model sebesar 90,40\% menerangkan bahwa kontribusi model untuk menjelaskan hubungan structural dari keempat variabel yang diteliti sebesar 90,40 \%. Sedangkan sisanya sebesar 9,60\% dijelaskan oleh variabel lain yang tidak terdapat dalam penelitian ini.

\section{Pengaruh Pelatihan $\left(\mathrm{X}_{1}\right)$ dan Lingkungan Organisasi $\left(\mathbf{X}_{2}\right)$ terhadap Kinerja Penyuluh Pertanian ( $\left.\mathbf{Y}_{2}\right)$ melalui Kompetensi Kerja $\left(\mathbf{Y}_{1}\right)$}

Variabel Pelatihan $\left(\mathrm{X}_{1}\right)$ dan Lingkungan Organisasi $\left(\mathrm{X}_{2}\right)$ memiliki pengaruh nyata terhadap Kinerja Penyuluh Pertanian $\left(\mathrm{Y}_{2}\right)$ melalui variabel antara (intervening) Kompetensi Kerja $\left(\mathrm{Y}_{1}\right)$. Hasil tersebut didapatkan dari penelitian yang telah dilakukan yang menunjukan bahwa nilai koefisien beta untuk Pelatihan sebesar 0,363 dengan nilai t sebesar 1,157 dan nilai Probabilitas sebesar 0,267 yang tingkat signifikansinya lebih kecil dibanding dengan nilai alpha $0,05(0,676<\alpha$ $=0,05)$. Pengaruh langsung variabel Pelatihan terhadap Kinerja Penyuluh Pelatihan sebesar 0,363, sedangkan pengaruh tidak langsungnya diperoleh dari $\mathrm{Px}_{1} \mathrm{y}_{1} \mathrm{x}$ $\mathrm{Py}_{1} \mathrm{y}_{2}=0,511 \times 0,184=0,094$, sehingga nilai total pengaruh Pelatihan terhadap Kinerja Penyuluhan Pertanian mencapai 0,363 $+0,094=0,457$.

Nilai tersebut menunjukan bahwa pengaruh Pelatihan terhadap Kinerja Penyuluhan Pertanian mengalami peningkatan, dimana pada awalnya sebesar 0,363 kemudian ditambah dengan pengaruh Kompetensi Kerja terhadap Kenerja Penyuluh Pertanian sebesar 0,094 sehingga diperoleh total pengaruh Pelatihan terhadap Kinerja Penyuluh Pertanian 
mencapai 0,457. Hal tersebut dapat disimpulkan bahwa dengan adanya variabel Kompetensi Kerja maka pengaruh Pelatihan terhadap Kinerja Penyuluh Pertanian semakin tinggi dan merupakan pengaruh yang positif. Mondy dan Wayne (2008) mengungkapkan bahwa pelatihan (training) adalah jantung dari upaya berkelanjutan untuk meningkatkan kompetensi karyawan dan kinerja organisasi.

Sedangkan pengaruh Lingkungan Organisasi $\left(\mathrm{X}_{2}\right)$ terhadap Kinerja Penyuluh Pertanian $\left(\mathrm{Y}_{2}\right)$ melalui variabel Kompetensi Kerja $\left(\mathrm{Y}_{1}\right)$ juga signifikan. Hal ini dibuktikan dari hasil penelitian yang menunjukan bahwa nilai koefisien beta sebesar 0,257 dengan nilai t sebesar 0,844 dan probalilitasnya sebesar 0,413 dimana tingkat signifikasi yang lebih kecil dibanding dengan nilai alpha $0,05((0,635<\alpha=0,05)$. Pengaruh langsung dari variabel Lingkungan Organisasi terhadap Kinerja Penyuluh Pertanian sebesar 0,257, namun ada pengaruh tidak langsungnya melalui variabel Kompetensi Kerja sebesar $\mathrm{Px}_{2} \mathrm{y}_{1} \times \mathrm{Py}_{1} \mathrm{y}_{2}=0,257 \times 0,184=0,047$, sehingga total pengaruh Lingkungan Organisasi terhadap Kinerja Penyuluh Pertanian mencapai 0,257 $+0,047=0,304$. Hal ini menunjukkan bahwa pengaruh Lingkungan Organisasi terhadap Kinerja Penyuluh Pertanian hanya mencapai 0,257, namun dengan adanya variabel Kompetensi Kerja akan mengalami peningkatan sebesar 0,047, sehingga menjadi sebesar 0,304. Sehingga dapat disimpulkan bahwa dengan adanya variabel Kompetensi Kerja maka pengaruh Lingkungan Organisasi terhadap Kinerja Penyuluh Pertanian semakin tinggi dan merupakan pengaruh yang positif.

Tujuan diselenggarakannya pelatihan adalah untuk meningkatkan kompetensi kerja peserta latihan agar lebih maksimal dalam mengerjakan pekerjaan dan tanggung jawab yang diembannya. Peningkatan kompetensi yang diperoleh selama mengikuti pelatihan tersebut, secara langsung maupun tidak langsung akan berdampak pada kinerja setiap petugas pada instansi kerjanya. Mangkunegara (2016) menyatakan bahwa kinerja merupakan hasil dari pekerjaan yang dicapai oleh karyawan, yang merupakan hasil kerja secara kualitas dan kuantitas dalam melaksanakan tugasnya sesuai dengan tanggung jawab yang diberikan kepadanya. Pelatihan yang diperoleh diharapkan mampu meningkatkan efektifitas kinerja karyawannya. Meningkatnya kinerja karyawan dapat digunakan sebagai bahan pertimbangan instansinya dalam pengembangan sumber daya manusia yang akan berdampak positif terhadap prestasi organisasinya. Organisasi harus memberikan kondisi lingkungan yang baik melalui kebijakan yang mendorong agar setiap karyawan mampu mengembangkan kompetensinya agar kinerjanya meningkat, sehingga prestasi organisasi dapat tercapai.

Masalah kinerja Penyuluh Pertanian tidak dapat dipisahkan dari kompetensi kerja dan lingkungan organisasi dalam melaksanakan tugas pokok dan fungsinya sebagai Penyuluh Pertanian. menurut Spencer dan Spencer (1993), kompetensi adalah segala bentuk motif, sikap, keterampilan, perilaku atau karakteristik pribadi lain yang penting untuk melaksanakan pekerjaan atau membedakan antara kinerja rata-rata dengan kinerja superior. Oleh karena itu organisasi membutuhkan sumber daya manusia yang memiliki kompetensi yang sesuai dengan kebutuhan dalam organisasi untuk meningkatkan kinerja Penyuluh Pertanian. Melalui peningkatan kompetensi kerja inilah maka kinerja Penyuluh Pertanian dapat ditingkatkan. Oleh karena itu maka Pelatihan dan Lingkungan Organisasi merupakan dua variabel yang mendukung peningkatan kompetensi kerja Penyuluh Pertanian yang berdampak pada pencapaian kinerja yang maksimal. Pemberian kesempatan kepada setiap Penyuluh Pertanian untuk mengikuti pelatihan yang dibutuhkan dan sesuai dengan tugas pokok dan fungsinya dan membangun lingkungan kerja yang kondusif akan mampu meningkatkan kompetensi kerja Penyuluh Pertanian yang pada akhirnya kinerjanya juga akan meningkat.

\section{KESIMPULAN DAN SARAN}

\section{Kesimpulan}

1. Variabel Pelatihan bagi Penyuluh Pertanian berpengaruh signifikan terhadap kompetensi kerjanya, Pelatihan yang didesian sesuai kebutuhan organisasi dan Penyuluh Pertanian akan meningkatkan Kompetensi Kerjanya.

2. Lingkungan organisasi juga berpengaruh signifikan terhadap kompetensi kerja Penyuluh Pertanian. Maka dengan semakin kuat dan kondusifnya lingkungan organisasi akan berpengaruh kepada Penyuluh Pertanian dalam meningkatkan kompetensi kerjanya.

3. Adanya pengaruh yang signifikan antara Kompetensi Kerja terhadap Kinerja Penyuluh Pertanian. Karena kompetensi kerja yang dipunyai Penyuluh Pertanian akan digunakan untuk memaksimalkan Kinerjanya dalam menyelesaikan pekerjaannya.

4. Pengaruh Pelatihan juga signifikan terhadap Kinerja Penyuluh Pertanian. Karena pelatihan didesain untuk memenuhi kebutuhan organisasi dan karyawannya dalam meningkatkan kinerjanya.

5. Pengaruh Lingkungan Organisasi menunjukan pengaruh yang positif dan signifikan terhadap Kinerja Penyuluh Pertanian. Maka dengan lingkungan organisasi yang kuat dan kondusif akan meningkatkan kompetensi dan kinerja Penyuluh Pertanian dalam pelaksanaan penyuluhan pertanian.

6. Berdasarkan hasil analisis menunjukan bahwa variabel Pelatihan dan Lingkungan Organisasi berpengaruh signifikan terhadap Kinerja Penyuluh Pertanian melalui Kompetensi Kerjanya. Hal ini ditunjukkan oleh adanya peningkatan dari pengaruh langsung dan pengaruh tidak langsung dari masingmasing variabelnya. 


\section{Saran}

1. Diharapkan agar Dinas Pertanian dan Peternakan Daerah Provinsi Sulawesi Utara memberikan dukungan kepada Penyuluh Pertanian yang seluas-luasnya dalam mengembangkan kompetensi kerja dan kinerjanya melalui Pelatihan. Pelatihan yang diselenggarakan harus benar-benar didesain sesuai dengan kebutuhan organisasi dan kebutuhan kompetensi Penyuluh Pertanian, sehingga pelatihan berjalan efektif dan dapat mendukung keberhasilan pembangunan pertanian.

2. Organisasi Penyuluhan Pertanian harus kuat, tidak berubah-ubah dan kondusif, agar mampu memberikan lingkungan organisasi yang baik terhadap para Penyuluh Pertanian dalam bekerja, sehingga kinerja Penyuluh Pertanian bisa dimaksimalkan.

3. Diharapkan agar hasil penelitian berguna untuk menambah wawasan serta memperdalam kajian pengetahuan tentang sumber daya manusia penyuluhan pertanian, khususnya pada masalah pelatihan, lingkungan organisasi dan kompetensi kerja, serta dapat dipakai sebagai studi lanjutan bagi para peneliti lainnya yang tertarik dibidang sumber daya manusia penyuluhan pertanian.

\section{DAFTAR PUSTAKA}

Anonimous, 1995, Membangun Ketangguhan Profesi Penyuluh Pertanian, Ekstensia, Vol 2, Tahun II, Jakarta, Pusat Penyuluhan Pertanian.

Badan Pengembangan SDM Pertanian, 2005, Penyelenggaraan Penyuluhan Pertanian, Rakernas Tahun 2005, Departemen Pertanian, Jakarta.

Bangun, Wilson, 2012, Manajemen Sumber Daya Manusia, Jakarta, Erlangga.

Boyatzis, RE, 1984, The Competent Manager: A Model For Effective Performance, New Tork, John Wilky \& Sons, Inc.

Bryant, C dan L.G. White, 1989, Manajemen Pembangunan Untuk Negara Berkembang, LP3ES Jakarta.

Gibson, 1999, Organisasi, Perilaku, Struktur, Proses, Jakarta, Inter Aksara.

Gomez Mejia, R. Luis dkk, 2001, Managing Human Resource, New Jersey, Prentice Hall.

Hasibuan, M.S.P, 2000, Manajemen Sumberdaya Manusia (Dasar dan Kunci Keberhasilan), Jakarta, PT. Gunung Agung.

Hubies, S dan A. Vitayala,1996, Mendinami-sasikan Partisipasi Kelompok Tani Nelayan dalam rangka Revitalisasi Penyuluhan Pertanian, Ekstensia, Volume IV Tahun III, Jakarta, Pusat Penyuluhan Pertanian.

Kasmir, 2016, Manajemen Sumber Daya Manusia (Teori dan Praktek), Edisi 1, Jakarta, Rajagrafindo Persada.
Mangkunegara, A.P, 2005, Evaluasi Kinerja SDM, Bandung, Refika Aditama.

Mangkunegara, A. P, 2016, Manajemen Sumber daya Manusia Perusahaan, Bandung, PT. Remaja Rosdakarya.

Martins, C.M, E.G. Gastanen, M. Lieberum, F. Lowen dan B. Seiffert, 1997, Indonesia Agricultural Extention Planning at A Crossroads, Berlin, Himboltdt Universitet $\mathrm{Zu}$ Berlin.

Moeheriono, 2009, Pengukuran Kinerja Berbasis Kompetensi, Jakarta, Ghalia Indonesia.

Mondy R. Wayne, 2008, Manajemen Sumber Daya Manusia, Edisi 10, Jilid 2, Jakarta, Erlangga.

Mosher, A.T, 1991, Menggerakan dan Membangun Pertanian, Jakarta, Yasaguna.

Notoatmodjo, S. 2003, Pengembangan Sumber Daya Manusia, Cetakan ketiga, Jakarta, PT. Rineka Cipta.

Nitisemito, 2000, Manajemen Personalia: Manajemen Sumber. Daya Manusia, Ed. 3. Jakarta, Ghalia Indonesia.

Padmowihardjo, S. 1994, Psikologi Belajar Mengajar, Jakarta, Universitas Terbuka.

Prawirosentono, S. 1992, Ilmu Manajemen Umum, Jakarta, Bumi Aksara

Rogers, E. M, 1983, Diffution of Innovations, New York, The Free Press.

Samsudin, V, 1977, Dasar-Dasar Penyuluhan dan Modernisasi Pertanian, Bandung, Bina Cipta.

Saragih, B, 2002, Pengaraan Menteri Pertanian RI dalam Rapat Kerja Nasional Badan PSDM Pertanian, Jakarta, Departemen Pertanian.

Soedarmanto, 1989, Dasar-Dasar Penyuluhan Pertanian, Malang, Universitas Brawijaya.

Spencer, 1993, At Work Competence Models For Superior Performance, New York, John Wilky \& Sons, Inc.

Spencer, M. Lyle dan M. Signe Spencer, 1993, Competence at Work, Modes For Superrior for Performance, New York, John Wilky \& Sons, Inc.

Sukriah, Erry, 2009, Modul Budaya dan Lingkungan Organisasi, Malang, Universitas Brawijaya.

Sumardjo, 1999, Tranformasi Model Penyuluhan Pertanian Menuju Pengembangan Kemandirian Petani, Disertasi Sekolah Pascasarjana, IPB Bogor.

Sumardjo, 2008, Perlukah Standarisasi Kompetensi, Makalah disajikan dalam Seminar Pemberdayaan Masyarakat, Fakultas Ekologi Manusia IPB Bogor, 7 Juli 2008.

Suparyadi, 2015, Manajemen Sumber Daya Manusia, Edisi 1, Yogyakarta, Andy Offset.

Tjitropranoto P. ,2003, Penyuluh Pertanian, Masa Kini dan Masa Depan, Di dalam Yustina I, Sudradjat A, Penyunting, Membentuk Pola Perilaku Manusia Pembangunan, Bogor, IPB Press.

Undang-Undang RI Nomor 16 Tahun 2006 tentang Sistem Penyuluhan Pertanian, Perikanan dan Kehutanan. Jakarta, Departemen Pertanian. 